\title{
Clinical experience with Tolvaptan outpatient use. Cost and effectiveness in 9 cases
}

\author{
David E. Barajas-Galindo, ${ }^{1 *}$ Alfonso Vidal-Casariego, ${ }^{1}$ Emilia Gómez-Hoyos ${ }^{2}$ and \\ María Guerra-González ${ }^{3}$ \\ ${ }^{1}$ Endocrinology and Nutrition Section, Complejo Asistencial Universitario de León, León; ' ${ }^{2}$ Department of Endocrinology and Nutrition, Hospital \\ Clínico Universitario, Valladolid; ${ }^{3}$ Hospital Pharmacy Department, Complejo Asistencial Universitario de León, León. Spain
}

\begin{abstract}
Introduction: Tolvaptan introduction has constituted the main therapeutic novelty in the management of hyponatremia in recent years. Objective: To describe the experience with this drug at Complejo Asistencial Universitario de León, Spain. Method: Retrospective, observational study of tolvaptan outpatient use in a tertiary care hospital from March 2014 to August 2017. Results: A total of 9 patients were treated with tolvaptan in the outpatient setting. Eunatremia was reached in 24 hours by $23.1 \%$. After tolvaptan administration, a reduction in days of hospitalization was recorded (361 vs. 70; $p=0.007$ ), especially in those days of hospitalization that were attributable to hyponatremia (306 vs. 49; $p=0.009$ ). Conclusions: Long-term use of tolvaptan appears to be safe and is associated with a decrease in days of hospitalization.
\end{abstract}

KEY WORDS: Tolvaptan. Hyponatremia. Sodium. Syndrome of inappropriate antidiuretic hormone secretion.

\section{Experiencia clínica con el uso ambulatorio de tolvaptan. Costes y efectividad en nueve casos}

\section{Resumen}

Introducción: La introducción de tolvaptan ha supuesto la principal novedad en el tratamiento de la hiponatremia en los últimos años. Objetivo: Describir la experiencia con tolvaptan en el Complejo Asistencial Universitario de León, España. Método: Estudio observacional retrospectivo de utilización ambulatoria de tolvaptan en un hospital de tercer nivel, de marzo de 2014 a agosto de 2017. Resultados: Fueron tratados con tolvaptan de forma ambulatoria nueve pacientes, $23.1 \%$ alcanzó eunatremia en 24 horas. Posterior a la administración de tolvaptan se registró reducción en días de hospitalización (361 versus $70, p=0.007$ ), especialmente por hiponatremia (306 versus $49, p=0.009$ ). Conclusiones: El uso a largo plazo de tolvaptan parece ser seguro y se relaciona con descenso en los días de hospitalización.

PALABRAS CLAVE: Tolvaptan. Hiponatremia. Sodio. Secreción inadecuada de hormona antidiurética.

\section{Introduction}

Hyponatremia, which is a decrease in serum sodium concentration below $135 \mathrm{mmol} / \mathrm{L}$, is the most prevalent electrolyte disorder in the outpatient and hospital setting. ${ }^{1}$ Its main cause is inadequate secretion of antidiuretic hormone, pathophysiologically caused by inability to suppress vasopressin secretion. ${ }^{2}$

Mild or moderate hyponatremia (serum sodium $[\mathrm{SNa}]=120-135 \mathrm{mmol} / \mathrm{L})$, which in many cases is chronically maintained, is associated with an increase in hospital ${ }^{3}$ and outpatient mortality, ${ }^{4}$ as well as with

\footnotetext{
Correspondence:

Date of reception: 30-04-2019

*David E. Barajas-Galindo

Date of acceptance: 30-05-2019

DOI: 10.24875/GMM.M19000323

Gac Med Mex. 2020;156:76-76

Contents available at PubMed

E-mail: dabarajas@saludcastillayleon.es

www.gacetamedicademexico.com

0016-3813/@ 2019 Academia Nacional de Medicina de México, A.C.. Published by Permanyer. This is an open access article under the CC BY-NC-ND license (http://creativecommons.org/licenses/by-nc-nd/4.0/).
} 
Table 1. Characteristics of patients receiving tolvaptan in the outpatient setting, according to hyponatremia etiology

\begin{tabular}{|c|c|c|c|c|c|c|c|c|c|c|c|c|}
\hline Variable & \multicolumn{2}{|c|}{$\begin{array}{c}\text { Pharmacological } \\
\text { SIADH } \\
n=3 \\
(33.3 \%)\end{array}$} & \multicolumn{2}{|c|}{$\begin{array}{c}\text { Paraneoplastic } \\
\text { SIADH } \\
n=2 \\
(22.2 \%)\end{array}$} & \multicolumn{2}{|c|}{$\begin{array}{c}\text { SIADH } \\
2^{\text {nd }} \text { neurological } \\
\text { condition } \\
n=2(22.2 \%)\end{array}$} & \multicolumn{2}{|c|}{$\begin{array}{c}\text { SIADH } \\
2^{\text {nd }} \text { respiratory } \\
\text { condition } \\
n=1(11.1 \%)\end{array}$} & \multicolumn{2}{|c|}{$\begin{array}{c}\text { Dilutional } \\
\text { hyponatremia } \\
\text { (cirrhosis) } \\
n=1(11.1 \%)\end{array}$} & \multicolumn{2}{|c|}{$\begin{array}{c}\text { Total } \\
\mathrm{n}=\mathbf{9}(\mathbf{1 0 0})\end{array}$} \\
\hline \multirow[t]{2}{*}{ Males/females (\%) } & \multicolumn{2}{|c|}{$33.3 / 66.6$} & \multicolumn{2}{|c|}{$100 / 0$} & \multicolumn{2}{|c|}{ 0/100 } & \multicolumn{2}{|c|}{$100 / 0$} & \multicolumn{2}{|c|}{$100 / 0$} & \multicolumn{2}{|c|}{$55.6 / 44.4$} \\
\hline & Me & DQ1-Q3 & Me & DQ1-Q3 & Me & DQ1-Q3 & Me & DQ1-Q3 & $\mathrm{Me}$ & DQ1-Q3 & Me & DQ1-Q3 \\
\hline Age (years) & 79.1 & 17.1 & 70.2 & 20.23 & 67.8 & 6.2 & 86.4 & 0 & 56.9 & 0 & 70.9 & 15.6 \\
\hline Baseline SNa (mmol/L) & 123 & 5 & 121 & 8 & 125.5 & 7 & 131 & 0 & 113 & 0 & 123 & 6 \\
\hline Final SNa (mmol/L) & 139 & 5 & 138.5 & 3 & 138.5 & 5 & 142 & 0 & 124 & 0 & 139 & 4 \\
\hline TV initial dose (mg/day) & 7.5 & 0 & 11.25 & 7.5 & 11.25 & 7.5 & 7.5 & 0 & 7.5 & 0 & 7.5 & 0 \\
\hline TV maintenance dose (mg/day) & 7.5 & 7.5 & 7.5 & 0 & 2.95 & 1.61 & 7.5 & 0 & 15 & 0 & 7.5 & 0 \\
\hline Treatment duration (days) & 770 & 500 & 92.5 & 79 & 596.5 & 985 & 730 & 0 & 61 & 0 & 277 & 630 \\
\hline
\end{tabular}

$\mathrm{SNa}=$ natremia, $\mathrm{TV}=$ tolvaptan, $\mathrm{SIADH}=$ syndrome of inappropriate diuretic hormone secretion, $\mathrm{Me}=$ median, $\mathrm{DQ} 1-\mathrm{Q} 3=$ diference between quartile 1 and quartile 3 .

an increase in instability, falls and fractures. ${ }^{5}$ The need to address its treatment has been emphasized in various consensus documents and clinical practice guidelines, ${ }^{6}$ which propose water restriction or increasing aquaresis with loop diuretics, urea or vasopressin V2 receptor antagonists, which constitute the main therapeutic novelty in its management; in Europe, tolvaptan (TV) is available. ${ }^{7}$

\section{Contribution to the scientific literature}

The purpose of this study was to assess costs and effectiveness of tolvaptan outpatient use at Complejo Asistencial Universitario de León, Spain, between March 2014 and August 2017, with the purpose to contribute some knowledge on the use of TV.

The hypothesis was proposed that hospitalization episodes and emergency department visits decrease with the use of TV with regard to the period without TV treatment. The elevated cost of this drug and the fact that it constitutes the main novelty in the treatment of hyponatremia in recent years motivated this report.

\section{Method}

Retrospective, observational study on the use of TV on an outpatient basis in a tertiary care hospital. All patients older than 18 years that were treated with tolvaptan between March 2014 and August 2017 were included. Data were collected from patient medical records. The information was anonymously handled.
The study variables were age, gender, reason for admission or visit to the emergency department, hospitalization and emergency department visit episodes before and after outpatient treatment, cause of hyponatremia, initial and maintenance dose, baseline and last available SNa measurement, treatment duration and treatment-related direct costs, calculated based on the manufacturer retail price, dispensed doses and number of days of treatment.

Statistical analysis was performed with Stata, version 14. The variables without normal distribution were described as medians and interquartile ranges and were compared using Mann-Whitney's U-test or Kruskal-Wallis test. Categorical variables were summarized as percentages and compared using the chi-square test. For all tests, statistical significance was considered with a $\mathrm{p}$-value $<0.05$.

This study was carried out in accordance with the guidelines established in the Fortaleza Declaration and all procedures performed on human subjects were approved by the Ethics and Clinical Research Committee of the hospital. Since this was a retrospective study, and given the difficulty to obtain informed consent of each patient, this was not applied.

\section{Results}

In total, nine patients received TV on an outpatient basis; their characteristics are summarized in Table 1.

The maintenance dose was lower than indicated in the summary of product characteristics ( $15 \mathrm{mg} /$ day) in seven patients, with eunatremia being achieved with 
Table 2. Cost of hyponatremia outpatient treatment with tolvaptan by etiology

\begin{tabular}{|c|c|c|c|c|c|c|}
\hline Variable & $\begin{array}{c}\text { Pharmacological } \\
\text { SIADH } \\
n=3(33.3 \%)\end{array}$ & $\begin{array}{c}\text { Paraneoplastic } \\
\text { SIADH } \\
n=2(22.2 \%)\end{array}$ & $\begin{array}{c}\text { SIADH } \\
2^{\text {nd }} \text { neurological } \\
\text { condition } \\
n=2(22.2 \%)\end{array}$ & $\begin{array}{c}\text { SIADH } \\
2^{\text {nd }} \text { respiratory } \\
\text { condition } \\
n=1(11.1 \%)\end{array}$ & $\begin{array}{c}\text { Dilutional } \\
\text { hyponatremia } \\
\text { (cirrhosis) } \\
n=1(11.1 \%)\end{array}$ & $\begin{array}{c}\text { Total } \\
\mathrm{n}=\mathbf{9}(100)\end{array}$ \\
\hline Treatment cost (DQ1-Q3), € & $\begin{array}{l}30766.1 \\
(27912.9)\end{array}$ & $\begin{array}{l}3236.3 \\
(994.9)\end{array}$ & $\begin{array}{l}16880.6 \\
(30759.8)\end{array}$ & $\begin{array}{c}27387.1 \\
(0)\end{array}$ & $\begin{array}{l}8714.5 \\
(0)\end{array}$ & $\begin{array}{l}17930.6 \\
(27033)\end{array}$ \\
\hline Total cost, € & 94540.3 & 6472.5 & 33761.3 & 27387.1 & 8714.5 & 170875.7 \\
\hline Total cost-day of treatment, $€$ & 163.7 & 79.9 & 44.1 & 37.5 & 142.9 & 39.9 \\
\hline $\begin{array}{l}\text { Total cost-admission } \\
\text { episodes } D, €\end{array}$ & 10504.5 & $0^{*}$ & 11253.8 & 13693.6 & $0^{*}$ & 21359.5 \\
\hline $\begin{array}{l}\text { Total cost-hospitalization } \\
\text { days } D, €\end{array}$ & 844.2 & 106.1 & 767.3 & 912.9 & 181.6 & 587.2 \\
\hline $\begin{array}{l}\text { Total cost-emergency } \\
\text { department visits } D, €\end{array}$ & 13505.8 & $0^{*}$ & 33761.3 & 13693.6 & $0^{*}$ & 24410.8 \\
\hline
\end{tabular}

$2.1 \mathrm{mg} /$ day (15 mg/seven days) in $11.1 \%$, with $3.75 \mathrm{mg} /$ day (7.5 mg/48 hours) in $22.2 \%$ and with $7.5 \mathrm{mg} /$ day (7.5 mg/24 hours) in $55.6 \%$.

There were no episodes of hypernatremia $(\mathrm{Na}>$ $145 \mathrm{mmol} / \mathrm{L}$ ) or acute renal failure during the follow-up.

When the periods of outpatient treatment with TV were compared in each patient with regard to equivalent periods of time prior to the start of treatment, we found a reduction in total days of hospitalization (361 versus $70, p=0.007$ ) at the expense of hospitalizations due to hyponatremia (306 versus $49, p=0.009$ ), with a trend towards a reduction in the number of total hospitalization episodes (19 versus $7, p=0.072$ ) and especially in those attributable to hyponatremia (14 versus $4, p=0.051$ ), as well as in episodes of aid at the emergency department for all causes (18 versus $11, p=0.302)$ and in those directly attributable to hyponatremia (15 versus $5, p=0.076$ ).

Outpatient treatment total cost during the analyzed period was $€ 170,875.7$ and mean cost per patient was $€ 17,930.6(3,733.7-30,766.1)$.

Table 2 shows the itemized expenditure per diagnosis and lists the cost and the recorded difference in assessed events: admission episodes, days of hospitalization and episodes requiring visits to the emergency department.

\section{Discussion}

In the analyzed patients, TV outpatient use was shown to be safe and efficacious in the reduction of clinical events, even with doses lower than those indicated in the summary of product characteristics.
Owing to the SALTWATER ${ }^{8}$ study, we have data available on the safety and efficacy of TV chronic use with regard to the evolution of natremia; however, experience is limited in terms of clinical benefits associated with the correction of natremia, which is restricted to the publication of clinical cases. ${ }^{9}$ In our patients, a follow-up of 3,993 days was accumulated, with a median of 277 days and a maximum individual follow-up of 1,089 days (2.98 years), which constitutes one of the strengths of the study. The use of TV appears to be associated with a significant decrease in days of hospitalization associated with hyponatremia and, overall, with any pathology; in addition, we identified a decrease in emergency department visits and admission episodes in patients treated with tolvaptan.

Of note, the majority of patients maintain eunatremia with the use of doses lower than those indicated in the summary of product characteristics. Along the same lines, the San Carlos Clinical Hospital group ${ }^{10}$ reported their follow-up results in 16 patients on outpatient treatment with TV for at least three years; they found reductions in hospital admissions, days of stay and visits to the emergency department.

It should be taken into account that the results vary significantly depending on the etiology of hyponatremia; for example, cancer patients attend the emergency department more often once they are treated, probably due to progression of the underlying disease. On the other hand, this is a non-randomized retrospective study and the number of patients is small, 
which constitutes the most important limitation of our study.

In the cost analysis, the expenses generated by ambulatory follow-up of the treated patients (medical appointments, laboratory tests, transportation, etc.) have not been taken into account, and neither have those related to admission or care at the emergency department; therefore, studies specifically designed to analyze the cost-effectiveness of this treatment would be necessary.

\section{Conclusions}

Long-term use of tolvaptan appears to be safe and could be related to a decrease in days of hospitalization due to hyponatremia.

\section{Funding}

This investigation did not receive public or commercial sector subsidy.

\section{Conflicts of interest}

David E. Barajas Galindo and Emilia Gómez Hoyos declare having received honoraria from Otsuka
Pharmaceutical Co. Ltd. for other works unrelated to this report.

\section{References}

1. Spasovski G, Vanholder R, Allolio B, Annane D, Ball S, Bichet D, et al. Clinical practice guideline on diagnosis and treatment of hyponatraemia. Eur J Endocrinol. 2014;170:G1-G47.

2. Peri $A$, Pirozzi N, Parenti G, Festuccia F, Menè $P$. Hyponatremia and the syndrome of inappropriate secretion of antidiuretic hormone (SIADH). J Endocrinol Invest. 2010;33:671-682.

3. Holland-Bill L, Christiansen CF, Heide-Jørgensen U, Ulrichsen SP Ring T, Jørgensen JO, et al. Hyponatremia and mortality risk: a Danish cohort study of 279508 acutely hospitalized patients. Eur J Endocrinol. 2015:173:71-81.

4. Sajadieh A, Binici Z, Mouridsen M, Nielsen OW, Hansen J, Haugaard SB. Mild hyponatremia carries a poor prognosis in community subjects. Am J Med. 2009;122:679-686.

5. Hoorn E, Rivadeneira F, van Meurs JB, Ziere G, Stricker BH, Hofman A, et al. Mild hyponatremia as a risk factor for fractures: the Rotterdam Study. J Bone Miner Res. 2011;26:1822-1828.

6. Verbalis JG, Goldsmith SR, Greenberg A, Korzelius C, Schrier RW, Sterns $\mathrm{RH}$, et al. Diagnosis, evaluation, and treatment of hyponatremia: expert panel recommendations. Am J Med. 2013;126:S1-S42.

7. European Medicines Agency. Samsca (tolvaptan). An overview of Samsca and why it is authorized in the EU. Reino Unido: European Medicines Agency; 2018.

8. Berl T, Quittnat-Pelletier F, Verbalis J et al. Oral tolvaptan is safe and effective in chronic hyponatremia. J Am Soc Nephrol. 2010;21:705-712.

9. Büttner S, Bachmann J, Geiger H, Obermüller N. Long-term vaptan treatment of idiopathic SIADH in an octogenarian. J Clin Med. 2017:6:28.

10. Cuesta-Hernández $M$, Crespo-Hernández I, Amich-Alemany $P$, Gómez-Hoyos E, Sánchez-Gómez N, Santiago A, et al. Correction of sustained hyponatremia secondary to SIAD by the use of chronic tolvaptan therapy is associated with a reduction in Emergency Room visits, hospital admissions and days of hospitalization over a 3-year period. Endocrine Abstracts. 2017;49:GP179. 